\title{
DC フラッシュ熱間溶接プロセスの加熱機構について*
}

\author{
土居 真**，藤岡 忠志** \\ Heating Mechanism of DC Flash Process for Hot Welding* \\ by DOI Makoto** and FUJIOKA Tadashi**
}

\begin{abstract}
It hasn't been well known which heat of joule and arc discharge is dominant factor in flash welding process. The objective of this study is to clarify heating mechanism of flashing. The flashing is a cycle consisting of local contact, joule heating, melting, spattering and arc discharge. Numerical model of flashing cycles was developed by assuming initial contact conditions. It has been evaluated heat input and welding parameters of DC flash welding. As the results, arc discharge heat is higher than joule heat for a wide range of flash current. Optimum flashing of DC is large contact and low frequency compared with general continuous flashing of AC. Heat input and platen velocities are $50 \%$ higher than those of AC at the same conditions and welding quality. The calculated velocities and crater depth of DC flashing are in good agreement with hot-billets welding data. It was found that DC flash welding compares very favorably with AC for short-time welding.
\end{abstract}

Key Words: Flash welding, Heating mechanism, Flashing cycle, Direct current, Numerical model, Short-time welding

\section{1. 緒言}

フラッシュ溶接は，大断面積部材の高能率溶接法であり， レール， $\mathrm{H}$ 型鋼1, 2)などの冷間材溶接や，工場ラインでのホ ットコイルの板継ぎ，ビレット接合 ${ }^{3,4)}$, 錨用大型チェーン などの短時間熱間溶接として実用化されている. ジュール 加熱のみで溶融圧接するアプセット溶接とは異なり，フラ ッシュ溶接では局所的な接触, ジュール加熱, 溶融飛散, 短時間アークのサイクルを高速に繰り返すことにより部材 端面が加熱される。このフラッシングと呼ばれる機構は多 量のスパッ夕発生を伴う高速の過渡現象のため, 加熱機構 の定量的な把握がほとんどなされていない. ジュール加熱 とアーク加熱との比率やスパッ夕消耗による入熱ロス等と フラッシングの大きさや回数によるそれらの変化は, 溶接 時間，フラッシュ量（フラッシュ時の部材消耗量）などの 溶接パラメータを決定し, 溶接効率や品質を左右する重要 な因子である．アークによる加熱が支配的であれば，非常 に小さなフラッシュを連続的に発生させることが, 部材端 面が平滑となり溶接欠陥が少なく入熱効率も良いことにな る. 逆に, アークは端面溶融部をスパッタさせ深く掘り込 み入熱もロスするため, 長期短絡のほうが入熱効率が良く 端面も平坦であるとする説もある. 今回熱間フラッシュ溶 接において, フラッシュ溶接の加熱機構を解明し, 最適な フラッシュ溶接プロセスを明らかにすることが本研究の目

\footnotetext{
*受付日 平成21年1月27日 受理日 平成21年 8 月24日 平成20 年 8 月溶接アーク物理研究で発表

**正 員 JFEエンジニアリング侏 Member, JFE Engineering Corporation
}

的である。

\section{2. フラッシングの簡易入熱モデル}

\section{1 フラッシングの基本機構について}

フラッシングの基本機構の説明図を Fig. 1 に示す. 上図
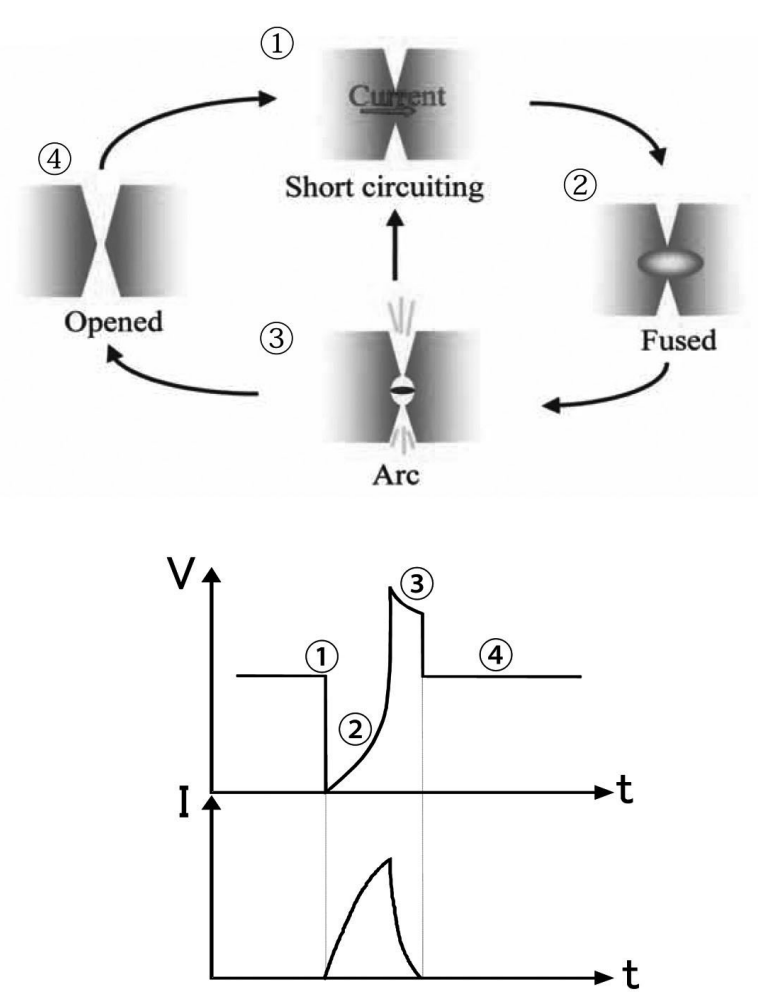

Fig. 1 Schematic illustration of flashing process and waveform of voltage and current. 
はフラッシングの 1 サイクルを表した模式図であり，下図 はそのときの電流電圧波形である. (4)の開放状態から部材 同士を接近させ局所的な接触短絡が発生すると電流が急激 に流れ始める (1)）。電流上昇とジュール加熱により急速に 接触領域が溶融し溶融ブリッジを形成する (2))。この溶融 ブリッジは，更なる電流上昇で溶融域が拡大する一方，電 磁ピンチ力も急激に増大するため短時間で破断する. 破断 後の溶融金属間のギャップには, 溶接回路インダクタンス に蓄えられたエネルギーによりアークが点弧し（3），溶融 金属を飛散させ，更に端面を加熱，溶融，飛散させる．フ ラッシュ溶接の印加電圧 $(6 〜 12 \mathrm{~V})$ はアークの維持電圧よ り低く, 蓄積エネルギーを放出し終わるとアークは消弧し, (4)の開放状態に戻り 1 サイクルが終了する.この 1 サイク ルの時間は，接触短絡の状態により変化するがおよそ $0.1 \mathrm{~ms}$ から $10 \mathrm{~ms}$ である。

\section{2 フラッシングのモデル化}

アプセット直前の定常フラッシュ状態を前提とし，部材 温度及び分布変化はないとする単純モデルを作成した。モ デルで考慮していない溶融部近傍のジュール加熱と温度上 昇, 周辺への熱拡散は, 部材の端面温度と温度分布を一定 に保つよう作用するとした．フラッシングは多点同時接触 からのマルチアーク発生を否定できないが，単一の接触短 絡とアークの繰返しであると仮定し，次のようにモデルを 作成した。まず，Fig. 2 に示すように全断面積 $\mathrm{S}_{\text {all }}$ の部材断 面を長さ $l_{\mathrm{s}}$ の正方形領域 $\mathrm{S}_{\text {short }}$ に等分し, その一つの領域が 凸となり接触し溶融ブリッジを形成する。この溶融長さ $\mathrm{d}_{\mathrm{s}}$ は予め与えられ一定であるとすると, 短絡によるジュール 加熱で溶融する体積 $\mathrm{V}_{\mathrm{s}}$ は $\mathrm{V}_{\mathrm{s}}=l_{\mathrm{s}}{ }^{2} \times \mathrm{d}_{\mathrm{s}}$ 与えられる。この短絡 溶融部 $\mathrm{V}_{\mathrm{s}}$ は電磁ピンチ力で破断後アーク発生と同時にすべ て飛散し，更にアークにより両端面から深さ $\mathrm{d}_{\mathrm{a}} / 2$ の領域が すべて溶融飛散する。アーク消弧直後に別の領域が接触し, 順次このフラッシングを繰り返す。このプロセスで端面へ の入熱を計算するための電圧，電流変化は，短絡時とアー ク時の各々で次のよう与えた。短絡時電流 $\mathrm{I}_{\mathrm{s}}$ は RL 直列回 路の直流電源 $\mathrm{ON}$ 時の過渡応答式 (1) とした。ここで， $\mathrm{R}_{\mathrm{s}}$ は

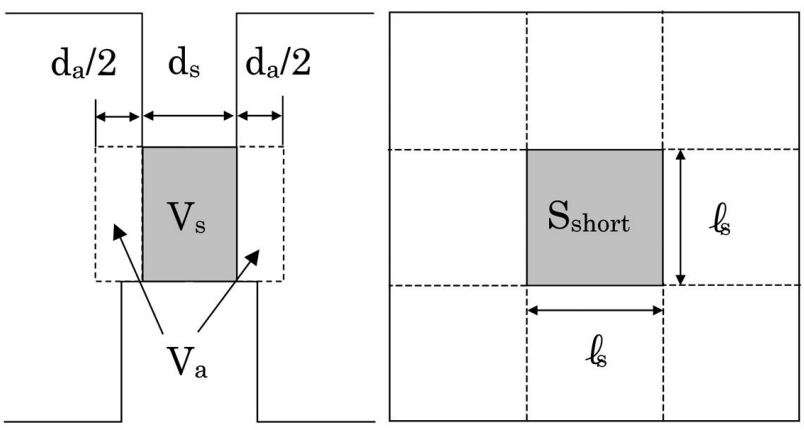

Fig. 2 Schematic diagram of simplified heating model of flashing.
Fig. 2 で仮定した短絡溶融部の抵抗值である.

$$
I_{s}=\frac{V_{0}}{R_{0}+R_{s}}\left[1-\exp \left(-\beta \frac{R_{0}+R_{s}}{L_{0}} t\right)\right]
$$

$\mathrm{V}_{0}$ ：無負荷電圧， $\mathrm{R}_{0}$ ：回路抵抗, $\mathrm{L}_{0}$ ：回路インダクタンス, $\mathrm{R}_{\mathrm{s}}$ : 短絡溶融部抵抗, $\beta$ : 時定数補正係数

短絡開始から，溶融ブリッジが電磁ピンチ力で破断する までの短絡時間 $\mathrm{t}_{\text {short }}$ は，溶融ブリッジ破断までの温度上昇 值を $\Delta \mathrm{T}$ とし，まず短絡接触部の必要熱量 $\mathrm{Q}_{\mathrm{m}}$ を求め次式の ジュール加熱式の積分計算により求めた。

$$
Q_{m}=\alpha \delta d_{s} l_{s}^{2} \Delta T, \quad Q_{m}=R_{s} \int_{0}^{t_{\text {short }}} I_{s}^{2} d t
$$

$a$ : 部材の比熱, $\delta$ : 部材の密度, $\Delta \mathrm{T}$ ：部材溶融ブリッジ 破断までの温度上昇值

溶融ブリッジが破断すると，Fig. 3 の等価回路では短絡抵
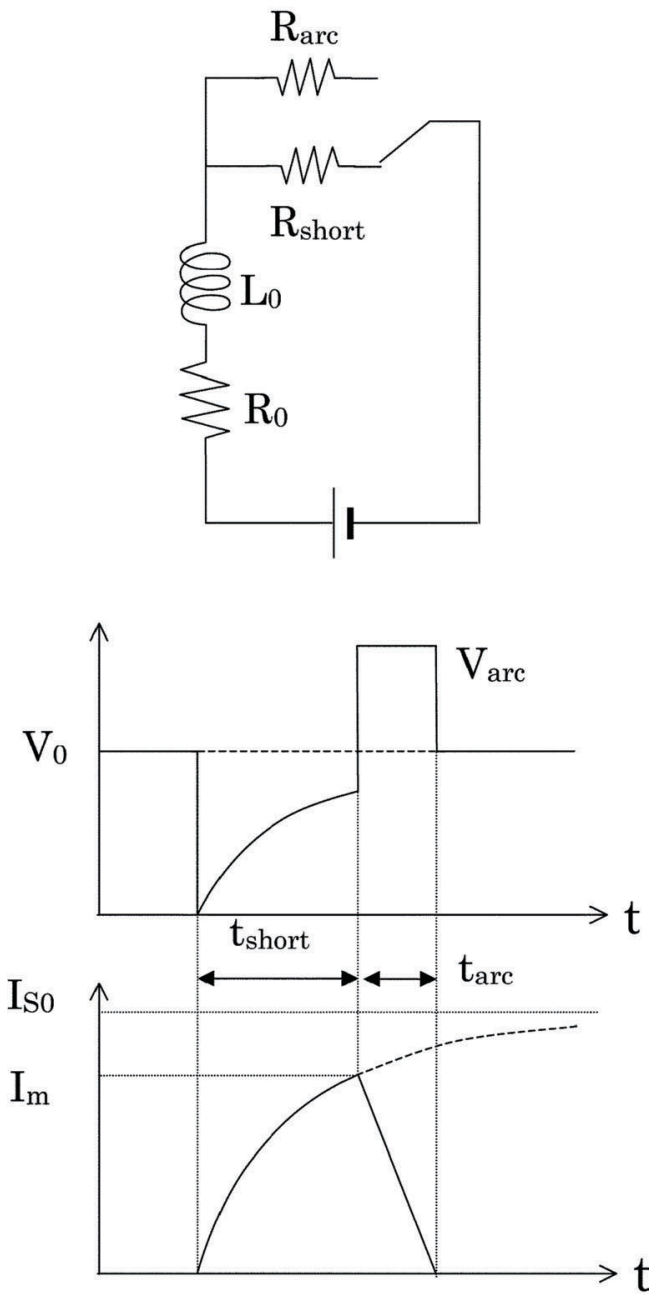

Fig. 3 Schematic illustration of equivalent welding circuit and waveform of voltage and current. 
抗 $\mathrm{R}_{\text {short }}$ 側の回路が切れ, アーク抵抗 $\mathrm{R}_{\mathrm{arc}}$ 側の回路が $\mathrm{ON}$ と なる. 実際のアーク過程の電流は短絡時の最大電流值 $\mathrm{I}_{\mathrm{m}}$ か ら指数的に減少しアーク電圧も若干低下するが，アーク電 流は一定の傾き $\mathrm{A}_{\mathrm{arc}}$ で減少しアーク電圧も一定であると単 純化した。 これによりアーク時間 $\mathrm{t}_{\mathrm{arc}}$, アーク電圧 $\mathrm{V}_{\mathrm{arc}}$, ア ーク入熱 $\mathrm{Q}_{\mathrm{arc}}$ は次のよう求まる.

$$
t_{\text {arc }}=\frac{I_{m}}{A_{\text {arc }}}, \quad V_{\text {arc }}=L_{0} A_{\text {arc }}+V_{0}, \quad Q_{\text {arc }}=\frac{1}{2} V_{\text {arc }} I_{m} t_{\text {arc }}
$$

傾き $\mathrm{A}_{\mathrm{arc}}$ については, 全短絡時の時定数 $\tau_{0}=\mathrm{L}_{0} / \mathrm{R}_{0}$ より下記 と定めた。この值の妥当性については， 4.3 節で実験結果に より検証する.

$$
A_{\text {arc }}=\frac{I_{0}}{\tau_{0}}=\frac{V_{0}}{L_{0}}
$$

そして，アークでの端面の溶融飛散による深さ $\mathrm{d}_{\mathrm{a}}$ は次式と なる。ここで，短絡溶融部はアーク発生と同時にすべて飛 散し，アーク加熱開始時に端面は短絡開始時と同温度であ り，また同じ温度上昇值 $\Delta \mathrm{T} に$ 昇温されることにより溶融 し飛散すると仮定した。この仮定は溶融ブリッジ破断には 強力な電磁ピンチ力が必要であり, その高電流密度による 溶融ブリッジ加熱とアークによる急激な端面加熱は同レべ ルと推定し, 短絡とアークの飛散時溶融部を同温度とした ことに基づく

$$
d_{a}=\frac{V_{a r c} I_{m}}{2 \alpha \delta l_{s}^{2} \Delta T}
$$

以上の式から，フラッシュ溶接でのフラッシングの発生 回数 (以下, フラッシュ回数), 部材送り速度（フラッシュ 速度）等の各種物理量や入熱值（以下フラッシングパラメ ータと総称）は下記のように求まる.

1）フラッシング周期, 回数

（周期） $\mathrm{t}_{\mathrm{pls}}=\mathrm{t}_{\mathrm{short}}+\mathrm{t}_{\mathrm{arc}}$ ，（回数） $\mathrm{n}_{\mathrm{pls}}=1 / \mathrm{t}_{\mathrm{pls}}$

2）短絡及びアーク入熱量

（短絡） $\mathrm{P}_{\text {short }}=\mathrm{Q}_{\text {shor }} / \mathrm{t}_{\mathrm{pls}} \quad\left(\right.$ アーク） $\mathrm{P}_{\mathrm{arc}}=\mathrm{Q}_{\mathrm{arc}} / \mathrm{t}_{\mathrm{pls}}$

3）全断面積フラッシング時間

$$
\mathrm{t}_{\text {all }}=\mathrm{t}_{\text {pls }} \times \mathrm{S}_{\text {all }} / \mathrm{S}_{\text {short }}
$$

4) フラッシュ速度 $\quad \mathrm{v}_{\mathrm{fl}}=\left(\mathrm{d}_{\mathrm{s}}+\mathrm{d}_{\mathrm{a}}\right) / \mathrm{t}_{\mathrm{all}}$

\section{3. 実 験 方 法}

実験に用いたフラッシュ溶接装置と測定システムの模式 図を Fig. 4 に示す。本研究では，スポット，シーム溶接な どの抵抗溶接に実用化されている IGBTインバータと DC 溶接トランスによるインバータ式 DC 電源を用いた。溶接 機は油圧による部材送り機構を備え, 溶接制御装置より部

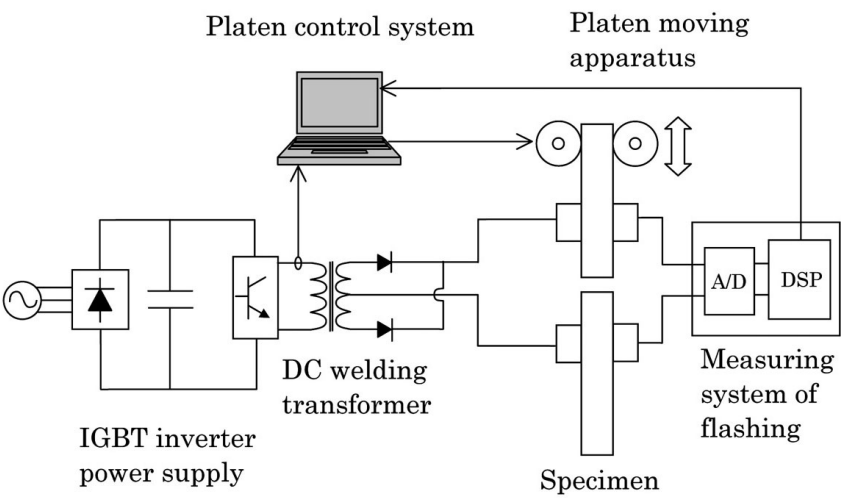

Fig. 4 Schematic diagram of flash welder and measuring system.

材送り速度や押し引き速度を設定し，インバー夕電源の出 力電流，電圧值によりその速度を最適に制御する装置とな っている．最大 $160 \mathrm{~mm}$ 角までの溶接が可能で，実験では 主に電気炉で約 $1100^{\circ} \mathrm{C}$ に加熱された $130 〜 150$ 角材の熱間 溶接を行った.

溶接時のフラッシングの状態は，部材給電部間の電圧を 測定し，デジタルシグナルプロセッサ（DSP）を用いた高 速演算処理によりフラッシュ回数変化やアーク時間分布を モニタできるシステムになっている，具体的には $200 \mu \mathrm{s}$ の 時間間隔で測定された変動電圧から，設定された閾值電圧 に対しての立上りから立下りまでの時間及びその間のピー ク電圧を求め，それぞれをアーク時間 $\mathrm{t}_{\mathrm{arc}}$ とアーク電圧 $\mathrm{V}_{\mathrm{arc}}$ とした.

\section{4. 計算及び実験結果}

\section{1 計算の前提条件について}

2 節で述べたモデルでは，計算の初期条件として短絡長 さ $\mathrm{d}_{\mathrm{s}}$ の設定が必要である.フラッシュ溶接中の短絡長さの 実測は困難であり，次のように推定した。まず円柱形溶融 ブリッジで自己電流による電磁ピンチ力の条件下，強制的 な液面振動が不安定とならない安定限界波長 $\lambda_{\mathrm{c}}$ は次式で与 えられる5

$$
\lambda_{c}=2 \pi r /\left(1+\frac{\mu_{0} I^{2}}{2 \pi^{2} r \gamma}\right)^{\frac{1}{2}}
$$

$\mathrm{r}$ : 溶融ブリッジ半径, $\mathrm{I}$ ：自己電流， $\mu_{0}$ ：真空の透磁率, $\gamma:$ 表面張力

溶接時に想定される溶融ブリッジ半径 1〜 40 mm の範囲 で (6) 式から求めた安定限界波長 $\lambda_{\mathrm{c}}$ は， 0.05 2.2 mm（平 均 $0.5 \mathrm{~mm}$ ）である。この值を短絡長さ $\mathrm{d}_{\mathrm{s}}$ とした場合の短絡 電流値は全半径範囲で全面接触電流值に近い大きな值とな $\eta$ ，安定限界波長 $\lambda_{\mathrm{c}}$ をそのまま短絡長さ $\mathrm{d}_{\mathrm{s}}$ とすることはで 
きない. 自己電流による弱い電磁ピンチ力で溶融ブリッジ が極短時間で破断するには, 強制的な液柱振動における安 定限界波長 $\lambda_{\mathrm{c}}$ を最低值としたより大きな短絡長さが必要と 考えられる. (6) 式から求めた前記半径範囲での溶融半径 $r$ と $\lambda_{\mathrm{c}}$ の関係は比例に近く, 短絡長さ $\mathrm{d}_{\mathrm{s}}$ と接触長さ $l_{\mathrm{s}}$ の 1 次 関係式を導入した。溶接を中断した端面のクレータサイズ は大きなもので直径 10〜20 mm, 深さ 2〜 $4 \mathrm{~mm} ゙$ あり ${ }^{0}$, 接 触短絡による溶融部もおおよそ同サイズ及び比と推定され

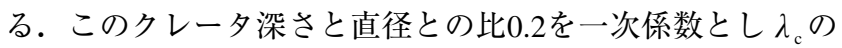
平均值 $0.5 \mathrm{~mm}$ を定数項とし, 短絡長さを $\mathrm{d}_{\mathrm{s}}=0.5+0.2 l_{\mathrm{s}}$ で 与えた。

もう一つ必要な条件は, 部材表面が接触短絡し加熱溶融 後飛散するまでの温度上昇值である．定常状態でのフラッ シュ中の部材表面温度は炭素鋼の融点レベルに達しており, 最初の接触短絡時温度は約 $1580^{\circ} \mathrm{C}$ と推定される. 形成され た溶融ブリッジは，ジュール加熱による急激な加熱により $2000^{\circ} \mathrm{C}$ から沸点の $3200^{\circ} \mathrm{C}$ まで達する可能性があるが, フラ ッシュにおいては電磁ピンチ力によってその温度上昇中に 破断すると考えられている。この溶融ブリッジの温度測定 は難しく報告例はないが, 同様の現象である $\mathrm{CO}_{2}$ アーク溶 接時溶滴の表面温度測定では, $1730 \sim 2830^{\circ} \mathrm{C}$ の広い温度分 布持つ結果が報告されている7). 中央值である $2280^{\circ} \mathrm{C}$ を溶 融ブリッジの破断直前温度とすると, 溶融ブリッジの温度 上昇値 $\Delta \mathrm{T}$ は $700^{\circ} \mathrm{C}$ となる.

また，実際のインバータ式 DC 電源では理想状態の DC に対し Fig. 4 に示した DC 溶接トランスの内部インピーダ ンスロスにより電流の立上り速度が低下することが測定に より分かっている.1本の部材をクランプし全短絡状態で の短絡試験時の電圧, 電流測定結果から, (1) 式の時定数の 補正係数 $\beta$ を 0.58 とした.

\section{2 計算結果}

150 角熱間ビレット（断面積 $\mathrm{S}=22500 \mathrm{~mm}^{2}$ ）を対象に, 短絡接触面積一定で面積值を 1 $1600 \mathrm{~mm}^{2}$ の範囲で計算し た結果を Fig. 5 と Fig. 6 に示す. 回路条件は, 無負荷電圧

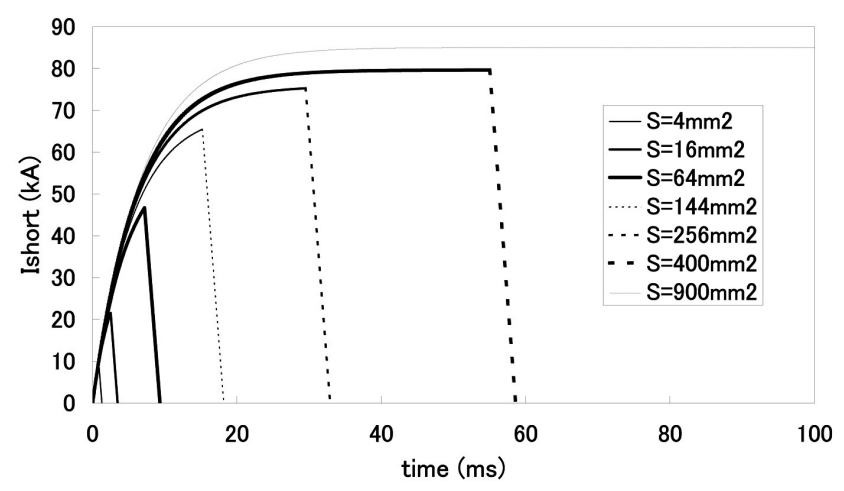

Fig. 5 Calculated current waveform varying in initial short contact area from 4 to $900 \mathrm{~mm}^{2}$.
$\mathrm{V}_{0}=7 \mathrm{~V}, 2$ 次回路インダクタンス $\mathrm{L}_{0}=0.318 \mu \mathrm{H}(60 \mathrm{~Hz}$ 換算 リアクタンス $\mathrm{X}=120 \mu \Omega)$ である. Fig. 5 は，短絡接触面 積 $\mathrm{S}_{\text {short }}=4 \sim 900 \mathrm{~mm}^{2}$ でのフラッシング時電流の時間変化を プロットしたものである. 接触面積の増加に従ってピーク 電流值が高くなり短絡時間も長くなることがわかる．接触 面積 $900 \mathrm{~mm}^{2}$ では電流值が飽和して $100 \mathrm{~ms}$ 以上の長期短絡 となり, 溶融ブリッジが切れないフリージングと呼ばれる 状態となっている.

Fig. 6 は，横軸に接触面積をとり，面積変化による短絡及 びアークの入熱量 $\mathrm{P}_{\text {short }}, \mathrm{P}_{\mathrm{arc}}$, フラッシュ回数 $\mathrm{n}_{\mathrm{fl}}$, フラッシ 工速度 $\mathrm{v}_{\mathrm{fl}}$ の変化及びフラッシングによる溶融飛散長さ $\mathrm{d}_{\mathrm{c}}=$ $\mathrm{d}_{\mathrm{s}}+\mathrm{d}_{\mathrm{a}}$ をプロットしたものである.フラッシュ回数は，接触 面積最小の $1 \mathrm{~mm}^{2} に$ に 1856 回/秒と非常に高いが，接触面積 増に従って急速に低下している。 入熱に関しては，接触面 積が小さい領域では短絡よりアークによる入熱が高く接触 面積 $100 \mathrm{~mm}^{2}$ でピークとなり，200 mm² 超えた面積でアー クと短絡の入熱が逆転する。接触面積 $144 \mathrm{~mm}^{2}$ においてフ ラッシュ回数は 55 回/秒で, フラッシュ速度はピーク值の $2.44 \mathrm{~mm} / \mathrm{sec}$ となり, 接触面積一定の理想状態における最適 条件と言える.フラッシングによる溶融飛散長さ $\mathrm{d}_{\mathrm{c}}$ は, 微 小面積領域を除くと 6 7 $\mathrm{mm}$ 程度で大きく変化しないこと がわかる.

実際の溶接では接触面積は一定ではなく大小の分布を持 ち, 溶接条件によりその分布幅が変化する。部材送り速度 や電流条件を上げるに従い，微小フラッシングの発生数が 減少しょり大きなフラッシングが発生するため, 接触面積 の分布範囲は拡大する。但し発生頻度分布は小フラッシン グが多く, 大フラッシングほど少なくなる傾向そのものは 変化しない。与えられた接触面積範囲を分割し，各面積で のフラッシングの占有時間比率（=フラッシング時間 $\times$ 発 生頻度／全接触面積数 m) が等しいとすると, 概ね実際の 分布状態での計算が可能である。つまり，Fig. 6 の単一接触 面積でのフラッシングパラメータ $\mathrm{f}_{\mathrm{p}}$ は単位時間当たりの量 であり，(7) 式に示す予め与えられた最大接触面積までの平 均化を行うことで, 実分布を考慮した条件でのフラッシン

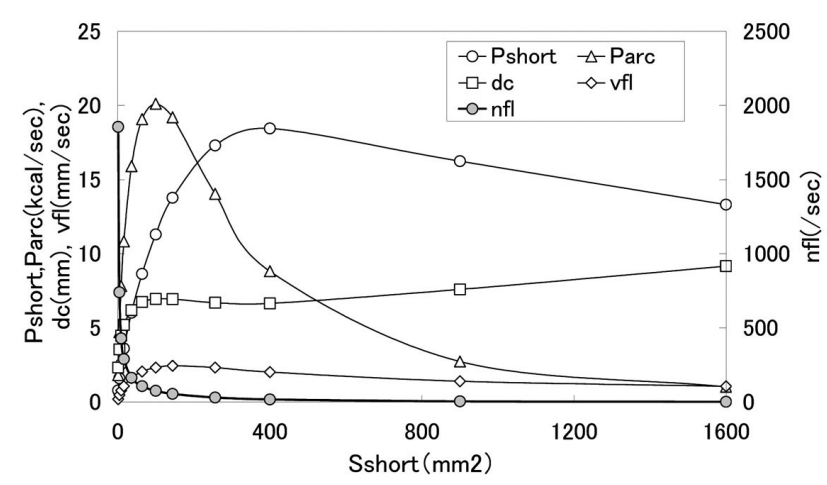

Fig. 6 Flashing parameters plotted against constant sectional area of initial short contact. 
グパラメータ $\mathrm{F}_{\mathrm{p}}$ を簡単に得ることが出来る。

$$
F_{p}\left(I_{m}\right)=\frac{1}{m} \sum_{n=1}^{m} f_{p}\left(s_{n}\right)
$$

ここで $\mathrm{S}_{\mathrm{n}}$ は各短絡接触面積, $\mathrm{I}_{\mathrm{m}}$ は最大接触面積での短絡電 流ピーク值である. Fig. 7 がその計算結果であり, 横軸には $\mathrm{I}_{\mathrm{m}}$ を取っている. ピーク電流值 $\mathrm{I}_{\mathrm{m}}$ は $15 \sim 88 \mathrm{kA}$ の広い範囲 にあり，電流上昇に従いフラッシュ回数は約 1000 回/秒から 約 300 回/秒まで減少する.Fig. 6 と異なりアークによる入 熱が短絡より常に高いことが分かる．フラッシング速度 $\mathrm{v}_{\mathrm{fl}}$ はほほ単調増加し, ピーク電流值 $\mathrm{I}_{\mathrm{m}}=80 \mathrm{kA}$ で最大 $1.53 \mathrm{~mm} / \mathrm{sec}$ となり Fig. 6 の最大值に対し $63 \%$ 小さくなって いる.また， $80 \mathrm{kA}$ 以上では溶融飛散長さ $\mathrm{d}_{\mathrm{c}}$ が急激に上が る結果となっている.

\section{3 実験結果による検証}

Fig. 4 に示したフラッシュ溶接装置とフラッシュ回数測定 システムを用いて計算結果の妥当性を，実験により検証し た。フラッシュ溶接装置は，通常連続フラッシュ方式鼻と言 われる部材送りのフィードバック制御がされており，イン バータの出力電流の基準值に対する差により部材の押し引 き速度を調整する．部材接触面積分布及びフラッシュ電流

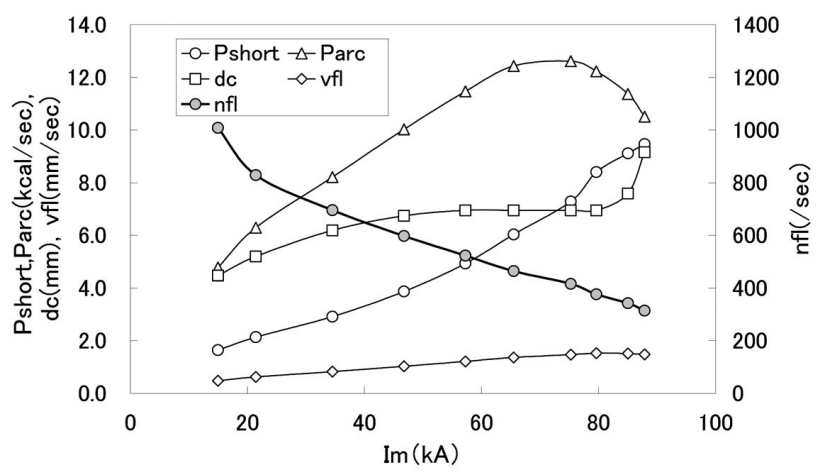

Fig. 7 Flashing parameters varying with distributed sectional area of initial short contact plotted against maximum peak current

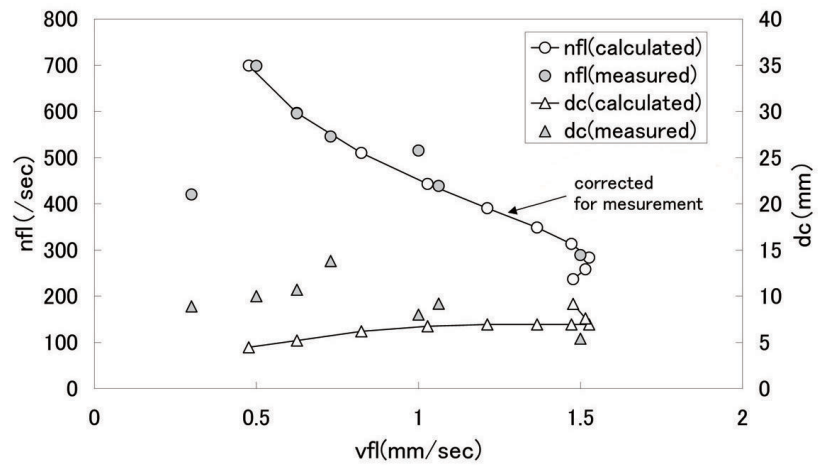

Fig. 8 Comparison between calculated flashing parameters and measured ones plotted against flashing velocity.
を変化させる実験ではフラッシュが定常になった状態で， 部材送りを 3 秒間一定速度にしその間のフラッシュ回数を 測定した。また 3 秒後にはアプセットせずに，そのまま部 材送りを停止し両端面の最大クレータ深さを測定した。測 定した結果と計算結果を横軸にフラッシュ速度をとり，プ ロットしたものがFig. 8 である。但し，フラッシュ速度 $1.5 \mathrm{~mm} / \mathrm{sec}$ については，定速度送りではフリージングする ため通常の電流フィードバック制御でのデータである。フ ラッシュ回数測定器はサンプリングが $200 \mu \mathrm{s}$ 間隔であるた め，アーク時間 $200 \mu \mathrm{s}$ 以下の微小なものについてはすべて を測定できない，計算での最小接触面積 $\left(\mathrm{S}_{\text {short }}=1 \mathrm{~mm}^{2}\right)$ 時 のアーク時間は $160 \mu \mathrm{s}$ であり，時間比の単純確率ではこの 面積でのフラッシュ回数の約 $1 / 4$ を測定できない. 確認のた めフラッシュ電圧を高速度記録計とフラッシュ回数測定器 で同時測定し，1 秒間の波形記録チャートからフラッシュ 回数を目視で正確にカウントし，測定器の結果と比較した. チャートのフラッシュ回数約 780 回/秒に対し，フラッシュ 回数測定器のデータは約 580 回/秒であった. 200 回/秒の差 はアーク時間 $160 \mu \mathrm{s}$ での計算回数の約半分であり，実際に は微小フラッシュの $1 / 2$ を測定できていないことが分かっ た．単純確率 $1 / 4$ との差は，実際のフラッシュではアーク時 間に分布を持つためであると考えられる.

Fig. 8 に示すようにフラッシュ回数の測定結果と最小フラ ッシュの計算回数值を $1 / 2$ とする補正を入れた計算結果を比 較すると両者は良く一致している。フラッシュ速度 $0.3 \mathrm{~mm} / \mathrm{sec} に て$ 回数が極端に低下しているのは，送り速度 が遅すぎて接触しない空送りの期間があるためである．実 測值の最大クレータ深さと計算での最大溶融飛散長さ $\mathrm{d}_{\mathrm{c}}$ の 比較では，送り速度 $1 \mathrm{~mm} / \mathrm{sec}$ 以上で計算に近い值となって いる。それより低速側でクレー夕深さが大きくなっている のは，入熱不足のためフラッシングが不安定となり長期短 絡が生じた結果と考えられる。

2 節のアーク過程モデル化において，アーク時の電流減 少の傾き $\mathrm{A}_{\mathrm{arc}}$ を一定值としたことの妥当性を，フラッシュ 回数測定器によるアーク時間分布と計算結果を比較するこ

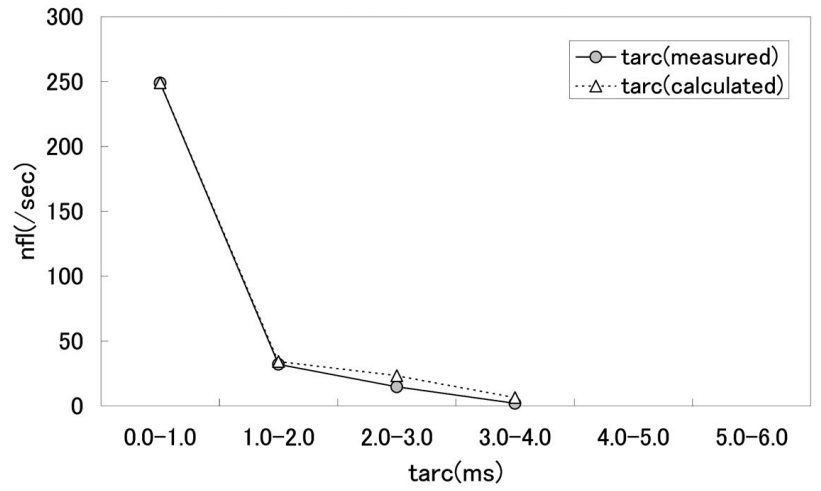

Fig. 9 Comparison between calculated distribution of arcing periods and measured one. 
とで検証した．横軸にアーク時間をとり $1 \mathrm{~ms}$ 間隔毎のフラ ッシュ回数分布の比較結果を示したのが Fig. 9 である. 実 測と計算の分布はほぼ一致し，アーク過程モデル化での傾 き一定によるアーク時間見積りは妥当であることを示して いる.

\section{5. フラッシュ溶接の最適プロセスについて}

前節の結果から DC フラッシュ溶接においては, Fig. 7 に 示したように短絡ピーク電流 $\mathrm{Im}=80 \mathrm{kA}$ ，フラッシュ回数 376 回/秒に, フラッシュ速度最大でクレータも深くない最 適条件がある.この結果はFig. 8 でのフラッシュ速度 $1.53 \mathrm{~mm} / \mathrm{sec}$, 補正フラッシュ回数 283 回/秒, クレータ深さ $6.95 \mathrm{~mm}$ の值となり, 実験結果においてもほぼ同じフラッ シュ速度, フラッシュ回数でクレータ深さも浅いことが確 認された。これまでの $\mathrm{AC}$ 方式で最適とされていた高いフ ラッシュ回数条件域とは大きく異なる高電流, 低回数条件 域に, 高フラッシュ速度かつ良品質の最適条件が DC 方式 にはあることが明らかになった。

しかしながら, インバータ DC 方式では溶接トランスで のインピーダンスロスがあり，この結果だけで AC 方式に 対する優位性を断言できない. 計算での最大短絡時間を $4 \mathrm{~ms}$ （60 HzAC の 1/4 周期）とする制限条件を $\mathrm{AC}$ の最適状 態とし，インバータ DC 方式の結果と比較した. AC 方式の 計算ではトランスのインピーダンスロスはなく, 極性反転 時のフラッシュ休止もない理想条件となる. 最大短絡時間 を $1 / 4$ 周期としたのは, AC フラッシュおいて半波の前半期 の電圧上昇時に短絡, 後半期の電圧下降時に細かなフラッ シング発生が理想的状態であることによる．1/4 周期以上の 短絡は，電流低下により溶融ブリッジが破断せず数周期以 上の長期短絡に至り，大きなクレータによる欠陷発生や AC 電流による入熱口スなど, 溶接品質, 溶接時間共に大きく 性能が低下することは明らかである.

理想状態での AC $60 \mathrm{~Hz}$ 時の計算結果を Fig. 10 に示す. 横軸は 2 次回路リアクタンス $\mathrm{X}_{0}$ であり，60 $\mathrm{N} \Omega$ は実用上の 最小值である．前節の DC 計算と同インダクタンス条件 120

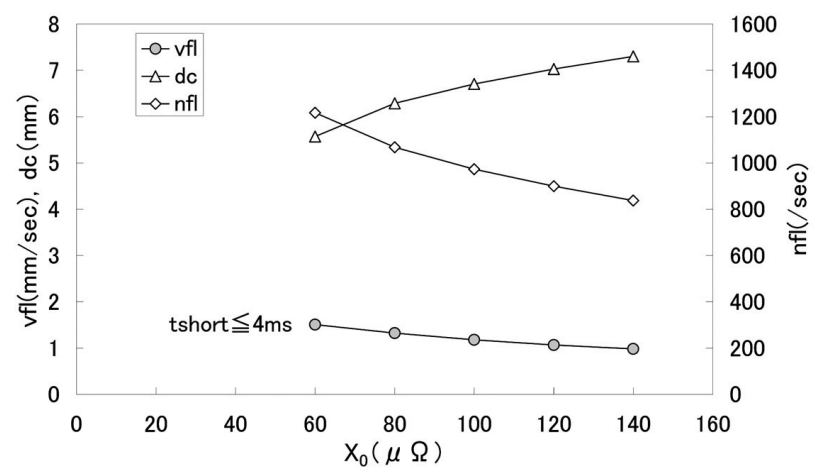

Fig. 10 Reactance dependence of AC flashing parameters calculated under theoretical conditions. $\mu \Omega$ で比較すると AC でのフラッシュ回数は, 900 回/秒と DC に対し 2.4 倍高く, 品質の指標となるクレータ深さ $\mathrm{d}_{\mathrm{c}}$ は, $7.03 \mathrm{~mm}$ で DC 方式の結果とほぼ同じである.フラッシュ速

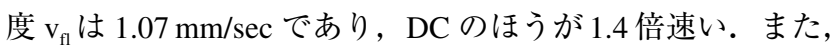
$120 \mu \Omega$ 時の最大短絡電流は，計算条件は異なるがおよそ Fig. 5 に示す $\mathrm{S}=16 \mathrm{~mm}^{2}$ と $\mathrm{S}=64 \mathrm{~mm}^{2}$ の間の波形となり，ピ ーク電流 $\mathrm{I}_{\mathrm{m}}$ の計算值は $32 \mathrm{kA}$ である. 最大短絡電流值は DC（80 kA）のほうが 2.5 倍高く端面への短絡入熱量は DC のほうが高い。以上の結果から，同インダクタンス条件の AC と DC の比較では，ほぼ同溶接品質で DC のほうがフラ ッシュ速度から推定すると約 $30 \%$ の溶接時間短縮が可能と なる。

\section{6. 結言}

高温ビレットの熱間溶接を対象に，DC フラッシュ溶接に おけるフラッシングの入熱現象を簡易モデル計算により調 べ，実験結果による検証を行った，得られた結果は以下の 通りである。

1）短絡接触面積と長さを一定とした単純モデルでは，接触 面積が小さいほうにアーク入熱，面積が大きいほうに短 絡入熱の 2 つのピークを持ち，その中間に両者を合わせ た入熱が最大值となる接触面積が存在することがわかっ た。また，この面積でのフラッシュ回数は54回/秒と非 常に少なく，大きな短絡が端面入熱及びフラッシングを 支配していることがわかった。

2）実際のフラッシングを模擬し接触面積分布を考慮した計 算結果では，フラッシュ速度が最大で品質も良好な最適 条件が，高電流条件領域にあることが分かった。

3）熱間ビレットの溶接実験おいて得られたフラッシュ速度 とフラッシュ回数の関係は，モデル計算結果と良く一致 した。また，クレータ深さの測定結果は計算の最適条件 において最も浅く，実溶接条件として最適かつ安定であ ることが分かった。

4）理想状態での AC 方式のモデル計算結果と DC 方式との 比較から，フラッシュ速度及び入熱において DC 方式の 優位性を確認した.

\section{参 考 文 献}

1) Y. Sato, E. Morishige, M. Ueda: Welding of Railroad Rails, Nippon Kokan Technical Report Oversears, vol. 47 (1986),72-76.

2) Y. Kim, K. Oku, A. Umekuni, K. Horikawa: Mechanical Properties of Rolled H Section Steel Jointed by Newly Developed Flash Welding System, Quarterly Journal of The Japan Welding Society, 21-1 (2003), 95-100. (in Japanese)

3) H. Wakasa, G. Matsuo, S. Okawa: Endless Rolling System for Bars and Rods, NKK Technical Review, No.81 (1999), 1-6.

4) H. Mukai, T. Fujioka, G. Matsuo, M. Fujii: Billet Flash Welder for Endless Rolling, NKK Technical Review, No.81 (1999), 7-12.

5) J. F. Lancaster: The Physics of Welding, kurokishuppan, (1990), 59-65. (in Japanese) 
6) 土居, 向井, 藤岡 : 大断面部材のフラッシュ溶接技術とその 溶接現象について, 第 145 回溶接アーク物理研究委員会, ア 物-02-1145 (2002).

7) K. Yamazaki, E. Yamamoto, K. Suzuki, F. Koshiishi, K. Waki, S.Tashiro, M.Tanaka, K.Nakata: The Measurement of Metal Droplet Temperature in GMA Welding by Infrared Two-Color Pyrometry,
Quarterly Journal of The Japan Welding Society, 26-3 (2008), 214219. (in Japanese)

8) 溶接学会軽構造接合加工研究委員会編：抵抗溶接現象とその 応用（VI）フラッシュ溶接,溶接学会技術資料 No.11, kurokishuppan, (1993). (in Japanese) 